\section{Calcium Sprays and Timing Affect Fruit Calcium Concentrations, Yield, Fruit Weight, and Cork Spot of 'Anjou' Pears}

\author{
J.T. Raese ${ }^{1}$ and S.R. Drake ${ }^{2}$ \\ U.S. Department of Agriculture, Agricultural Research Service, Tree Fruit \\ Research Laboratory, 1104 North Western Avenue, Wenatchee, WA 98801
}

Additional index words. Pyrus communis, fruit disorders, mineral nutrition, quality

\begin{abstract}
Calcium sprays ( $\mathrm{CaCl}_{2}$, Mora-Leaf-Ca + Link Ca, or Stopit) increased fruit Ca concentrations and reduced the incidence of cork spot of 'Anjou' pears (Pyrus communis L.) during four seasons. All Ca sprays increased yield relative to the control. All sprays resulted in some injury to leaves and fruit, but fruit was acceptable for marketing. At the low rate, Stopit sprays were the least injurious. Early season sprays, in June to July, produced less leaf and fruit injury than late-season sprays, in July to August, or early + late-season sprays. Early or late-season Ca sprays resulted in slightly larger fruit than early + late sprays. Either late or early + late-season sprays led to higher Ca concentrations in fruit cortex than early sprays.
\end{abstract}

Because potential Ca spray injury to 'Anjou' pear leaves and fruit has been a concern in the Pacific Northwest, Ca sprays were not recommended until the mid-1980s. Raese and Stahly (1982) reported that halving calcium chloride $\left(\mathrm{CaCl}_{2}\right)$ rates recommended for apple to only $179 \mathrm{~g} / 100$ liters or using a surfactant (Regulaid) with $\mathrm{CaCl}_{2}$ reduced spray injury to leaves and fruit of 'Anjou' pears.

Adequate $\mathrm{Ca}$ in fruit of 'Anjou' pears is necessary for control of certain disorders, especially cork spot (Mason and Welsh, 1970; Raese, 1989; Richardson and Al-Ani, 1982; Woodbridge, 1971). Calcium sprays are one way of increasing Ca in fruit of 'Anjou' pears (Raese, 1988; Raese and Drake, 1993; Raese and Stahly, 1982; Richardson and Lombard, 1979).

The most effective time of the growing season to apply $\mathrm{Ca}$ has not been established. Since growing conditions vary with each season, it is important to examine the effects of spraying 'Anjou' trees with $\mathrm{Ca}$ at various times of the growing season over several years. For example, a 1-year study indicated that a single application of Ca spray in July or August was more effective for control of cork spot of 'Anjou' pear than a single spray in May or June, yet two early season sprays (May and

Received for publication 22 Aug. 1994. Accepted for publication 14 Apr. 1995. This research was supported in part by the Winter Pear Control Committee of the Washington, Oregon, California Pear Bureau. We appreciate the cooperation at Bitterman and Flick Orchard, and to F. Valentine, Fieldman. Mention of a trade name, proprietary product, or specific equipment does not constitute a guarantee or warranty by the U.S. Dept. of Agriculture and does not imply its approval to the exclusion of other products that may be suitable. The cost of publishing this paper was defrayed in part by the payment of page charges. Under postal regulations, this paper therefore must be hereby marked advertisement solely to indicate this fact.

${ }^{1}$ Plant Physiologist (Collaborator), retired

${ }^{2}$ Research Horticulturist.
June) of Ca were slightly more effective than two sprays in July and August (Richardson and Lombard, 1979).

The goals of our study were to determine an effective Ca spray material and spray timing for increasing fruit $\mathrm{Ca}$ concentrations and reducing the incidence of cork spot while limiting Ca-spray phytotoxicity to leaves and fruit of 'Anjou' pears to acceptable levels.

\section{Materials and Methods}

A uniform block of 25-year-old 'Anjou' pear trees grown on 'Bartlett' pear seedling rootstocks was selected for the study. Trees were spaced at $6.4 \times 5.5 \mathrm{~m}$ with a guard tree separating sprayed trees and a grass cover crop growing underneath. The orchard was located near Cashmere, Wash. The soil was a Burch and $26.2 \mathrm{C}$ for $1986,1987,1988$, and 1989 , respectively).

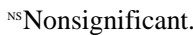

fine sandy loam with a $10 \%$ slope having a southern exposure.

In each of 4 years (1986-89), five treatments were randomly assigned to 75 trees, making five single-tree replications for each of four Ca materials and an unsprayed control in this randomized split-block design. Calcium chloride (granules of $\mathrm{CaCl}_{2}$ as $34 \% \mathrm{Ca}$ ), $\mathrm{CaCl}_{2}+$ Regulaid or Activate (surfactants), Mora-leaf-Ca + Link-Ca (34 and 6\% Ca, respectively; Wilbur-Ellis Co., Wenatchee, Wash.), Stopit (a liquid $\mathrm{CaCl}_{2}, 12 \% \mathrm{Ca}+$ surfactant; Shield Brite Corp., Kirkand, Wash.), and the unsprayed controls were assigned to the same trees over the 4 years. All Ca sprays were applied with a handgun until runoff at rates suggested by the manufacturers. In our experiment, $\mathrm{CaCl}_{2}, \mathrm{CaCl}_{2}+$ Regulaid, and Mora-leaf-Ca + Link Ca were all applied at the same rate of actual $\mathrm{Ca}$, but Stopit was applied at $30 \%$ less (Table 1).

A group of 25 trees received early sprays that consisted of applications in early June, late June, and mid-July, while the late sprays were applied to the second group of 25 trees in mid-July, early August, and late August. A third group of 25 trees received the early plus late sprays at the times indicated for a total of five applications.

Observations on leaf or fruit injury from $\mathrm{Ca}$ sprays were made on the same day as the spray applications. Ratings of spray injury to leaves and fruit were determined by J.T.R., where $1=$ very slight, 3 = borderline accept able, and $5=$ very severe injury. Temperature, humidity, cloud cover, and wind movement also were recorded during each spray period. Visual estimates (ratings described in Tables 1 and 2) of crop load (yield) and incidence of fruit disorders (alfalfa greening, black end, and cork spot) were determined at harvest time in early September. A 10-fruit sample from each tree was collected and stored for 4 to 6 months at $-1.0 \mathrm{C}$, after which fruit were washed

Table 1. Effect of Ca sprays, timing, and year of application on fruit weight, Ca concentrations in fruit peel and cortex, and incidence of cork spot of 'Anjou' pears at harvest, 1986 to $1989 .{ }^{2}$

\begin{tabular}{|c|c|c|c|c|c|}
\hline \multirow[b]{2}{*}{$\underline{\text { Variable }}$} & \multirow{2}{*}{$\begin{array}{c}\mathrm{Ca} / 100 \text { liters } \\
\text { of water }\end{array}$} & \multirow{2}{*}{$\begin{array}{l}\text { Fruit wt } \\
\text { (g) }\end{array}$} & \multicolumn{2}{|c|}{$\begin{array}{l}\text { Fruit Ca concn } \\
\left(\mu \mathrm{g} \cdot \mathrm{g}^{-1}, \text { dry wt }\right)\end{array}$} & \multirow{2}{*}{$\begin{array}{c}\text { Cork spot } \\
\text { (no. fruit/tree) }\end{array}$} \\
\hline & & & Peel & Cortex & \\
\hline \multicolumn{6}{|l|}{$\overline{\text { Calcium materials }}$} \\
\hline Control & None & $196^{\mathrm{NS}}$ & $1642 \mathrm{~b}$ & $479 \mathrm{c}$ & $8.9 \mathrm{a}$ \\
\hline $\mathrm{CaCl}_{2}(34 \% \mathrm{Ca})$ & $60.5 \mathrm{~g}$ & 195 & $1789 a$ & $534 \mathrm{a}$ & $1.6 \mathrm{c}$ \\
\hline $\mathrm{CaCl}_{2}+$ Regulaid & $\begin{array}{r}60.5 \mathrm{~g}+ \\
62.4 \mathrm{ml}\end{array}$ & 195 & $1675 \mathrm{~b}$ & $493 \mathrm{bc}$ & $3.9 \mathrm{~b}$ \\
\hline Stopit $(12 \% \mathrm{Ca})$ & $42.1 \mathrm{~g}$ & 195 & $1723 \mathrm{ab}$ & $519 a b$ & $3.9 \mathrm{~b}$ \\
\hline \multicolumn{6}{|l|}{ Mora-leaf-Ca $(34 \%$ Ca $)+$} \\
\hline Link $\mathrm{Ca}(6 \% \mathrm{Ca})$ & $\begin{array}{l}40.5 \mathrm{~g}+ \\
20 \mathrm{~g}\end{array}$ & 195 & $1723 \mathrm{ab}$ & $526 \mathrm{a}$ & $3.3 \mathrm{~b}$ \\
\hline \multicolumn{6}{|l|}{ Spray timing } \\
\hline Early (June-July) & & $197 \mathrm{a}$ & $1676 \mathrm{~b}$ & $487 \mathrm{~b}$ & $4.7^{\mathrm{Ns}}$ \\
\hline Late (July-August) & & 197 a & $1741 \mathrm{a}$ & $513 \mathrm{a}$ & 4.3 \\
\hline Early + late (June-August) & & $192 \mathrm{~b}$ & $1714 \mathrm{ab}$ & $531 \mathrm{a}$ & 3.9 \\
\hline \multicolumn{6}{|l|}{ Year of application ${ }^{y}$} \\
\hline 1986 & & $185 \mathrm{~d}$ & $1766 \mathrm{~b}$ & $526 \mathrm{a}$ & $3.0 \mathrm{c}$ \\
\hline 1987 & & $211 \mathrm{a}$ & $1480 \mathrm{~d}$ & $520 \mathrm{a}$ & $7.0 \mathrm{a}$ \\
\hline 1988 & & $190 \mathrm{c}$ & $1665 \mathrm{c}$ & $469 \mathrm{~b}$ & $2.6 \mathrm{c}$ \\
\hline 1989 & & $195 \mathrm{~b}$ & $1930 \mathrm{a}$ & $526 \mathrm{a}$ & $4.6 \mathrm{~b}$ \\
\hline
\end{tabular}

${ }^{2}$ Means within columns separated by Duncan's multiple range test, $P \leq 0.05$.

${ }^{y}$ Average of monthly maximum temperatures from April through September for each year (25.2, 26.8, 25.7, 
and weighed. Overall appearance, fruit color, rots, and incidences of fruit disorders were visually assessed, and mineral nutrient content $(\mathrm{N}, \mathrm{P}, \mathrm{K}, \mathrm{Ca}, \mathrm{Mg}, \mathrm{Al}, \mathrm{B}, \mathrm{Cu}, \mathrm{Fe}, \mathrm{Mn}, \mathrm{Na}$, and $\mathrm{Zn}$ ) was measured. Total $\mathrm{N}$ was determined with a Leco FP $228 \mathrm{~N}$ Analyzer (St. Joseph, Mich.) and the other nutrient concentrations were made with a Beckman Spectrospan V plasma emission spectrometer (Brea, Calif.). Whole fruit samples were divided into peel and cortex (flesh) wedges for mineral nutrient analysis, using two sections on adjacent sides of the blush side of fruit (Raese and Staiff, 1983). The core and seeds were excluded.

A model EP1 pressure tester (Lake City, Kelowna, B.C., Canada) equipped with a 7.8$\mathrm{mm}$ head was used to determine firmness on peeled fruit. Juice prepared from pear slices was titrated to $\mathrm{pH} 8.2$ with $0.1 \mathrm{~N} \mathrm{NaOH}$ and values were expressed as percentage of malic acid. Soluble solid concentration (SSC) was determined with an Abbe-type refractometer calibrated at $20 \mathrm{C}$.

Analysis of variance was conducted by MSTAT (Michigan State Univ., 1988) with Ca sprays as the main plots and spray timing and years of application as subplots with five single-tree replications. Based on significant $F$ values, treatment means were separated by Duncan's multiple range test. No interactions occurred between Ca spray materials and spray timing; therefore, only the main effects are presented.

\section{Results}

Fruit weight, fruit $\mathrm{Ca}$, and cork spot. $\mathrm{Cal}-$ cium spray materials had no effect on fruit weight, but five sprays from June to August resulted in smaller fruit than three sprays in June to July or July to August (Table 1). Fruit weight was influenced by year of spray application and fruit was largest (heaviest) in 1987, when seasonal temperature was highest. Fruit peel $\mathrm{Ca}$ concentration was higher on trees sprayed with $\mathrm{CaCl}_{2}$ than on the controls, while higher fruit cortex $\mathrm{Ca}$ resulted from $\mathrm{CaCl}_{2}$, Stopit, and Mora-leaf-Ca (Table 1). Calcium in fruit peel or cortex was lowest from trees receiving the early sprays. Highest concentrations in fruit peel occurred in 1989, while concentrations of $\mathrm{Ca}$ in fruit cortex were about equal in 1986, 1987, and 1989 and higher than in 1988. Best control of cork spot occurred with $\mathrm{CaCl}_{2}$ sprays, but the incidence of cork spot was apparently not influenced by spray timing. The incidence of cork spot was highest in 1987. Alfalfa greening and black end were present, but they were not as severe as cork spot. However, the incidence of alfalfa greening and black end were significantly higher for the early than late $\mathrm{Ca}$ spray treatments (data not shown).

Yield and Ca spray injury. Yield was higher on trees receiving any of the Ca spray treatments than on unsprayed trees (Table 2). Yield was higher from trees sprayed late with $\mathrm{Ca}$ than with early + late sprays. Yield increased each year from 1986 to 1989 . More spray injury to leaves occurred on trees sprayed with
$\mathrm{CaCl}_{2}$ or Mora-leaf-Ca + Link Ca than with the other treatments (Table 2). Leaf injury was more severe on trees sprayed five times (early + late) from June to August than on the others. Most severe leaf injury occurred in 1988 and least in 1986 and 1989. Most severe injury to fruit was observed in the orchard on trees sprayed with Mora-leaf-Ca + Link Ca (Table 2 ); the least spray injury to fruit occurred on trees sprayed early (June to July) and in 1986. After washing and rating fruit samples in the laboratory, fruit spray injury was less from trees sprayed with Stopit or Mora-leaf-Ca + Link $\mathrm{Ca}$ than from the $\mathrm{CaCl}_{2}$ or $\mathrm{CaCl}_{2}+$ Regulaid treatments (Table 2). After washing the fruit, injury from sprays was highest for early + late sprays and from trees sprayed in 1989.

Fruit quality. Fruit firmness was not influenced by Ca materials or time of spray and the values ranged from 49.1 to $50.1 \mathrm{~N}$. However, fruit firmness was higher in 1986 and 1989 than in 1987 or 1988 (Table 3). Neither SSC (12.6 to 12.8$)$, nor titratable acidity (TA) $(0.278$ to 0.289 ), nor fruit color ratings (1.6 to 1.9 ) were different among Ca treatments or time of spray application. But, SSC was highest in 1988, TA was highest in 1986 , while fruit color was greenest in 1989 (Table 3).

Table 2. Effect of Ca sprays, timing, and year of application on yield, and spray injury to leaves and fruit of 'Anjou' pears, 1986 to 1989.

\begin{tabular}{|c|c|c|c|c|c|}
\hline \multirow[b]{3}{*}{ Variable } & \multirow[b]{3}{*}{$\begin{array}{l}\mathrm{Ca} / 100 \text { liters } \\
\text { of water }\end{array}$} & \multirow{3}{*}{$\begin{array}{c}\text { Yield } \\
\text { (kg/tree } \\
\text { per year) }\end{array}$} & \multicolumn{3}{|c|}{ Ca spray injury ${ }^{2}$} \\
\hline & & & \multirow[b]{2}{*}{ Leaves } & \multicolumn{2}{|c|}{ Fruit } \\
\hline & & & & $\begin{array}{c}\text { In } \\
\text { orchard }\end{array}$ & $\begin{array}{c}\text { In } \\
\text { storage }\end{array}$ \\
\hline \multicolumn{6}{|l|}{ Calcium materials } \\
\hline Control & None & $171 b^{x}$ & $0.5 \mathrm{~d}$ & $0.6 \mathrm{e}$ & $0.3 \mathrm{~d}$ \\
\hline $\mathrm{CaCl}_{2}(34 \% \mathrm{Ca})$ & $60.5 \mathrm{~g}$ & 194 a & $2.3 \mathrm{a}$ & $2.4 \mathrm{~b}$ & $1.3 \mathrm{a}$ \\
\hline $\mathrm{CaCl}_{2}+$ Regulaid & $\begin{array}{r}60.5 \mathrm{~g}+ \\
62.4 \mathrm{ml}\end{array}$ & 204 a & $2.0 \mathrm{~b}$ & $2.0 \mathrm{c}$ & $1.3 \mathrm{a}$ \\
\hline Stopit (12\% Ca) & $42.1 \mathrm{~g}$ & $202 \mathrm{a}$ & $1.5 \mathrm{c}$ & $1.8 \mathrm{~d}$ & $0.9 \mathrm{c}$ \\
\hline $\begin{array}{l}\text { Mora-leaf-Ca }(34 \% \mathrm{Ca}) \\
\text { + Link Ca }(6 \% \mathrm{Ca})\end{array}$ & $\begin{array}{l}40.5 \mathrm{~g}+ \\
20 \mathrm{~g}\end{array}$ & 199 a & $2.4 \mathrm{a}$ & $2.8 \mathrm{a}$ & $1.1 \mathrm{~b}$ \\
\hline \multicolumn{6}{|l|}{ Spray timing } \\
\hline Early (June-July) & & $193 \mathrm{ab}$ & $1.4 \mathrm{c}$ & $1.6 \mathrm{~b}$ & $0.9 \mathrm{~b}$ \\
\hline Late (July-August) & & $205 \mathrm{a}$ & $1.8 \mathrm{~b}$ & $2.1 \mathrm{a}$ & $0.9 \mathrm{~b}$ \\
\hline Early + late (June-August) & & $183 \mathrm{~b}$ & $2.0 \mathrm{a}$ & $2.1 \mathrm{a}$ & $1.1 \mathrm{a}$ \\
\hline \multicolumn{6}{|l|}{ Year of application ${ }^{\mathrm{w}}$} \\
\hline 1986 & & $88 \mathrm{~d}$ & $1.5 \mathrm{c}$ & $1.7 \mathrm{~b}$ & $0.7 \mathrm{c}$ \\
\hline 1987 & & $197 \mathrm{c}$ & $1.8 \mathrm{~b}$ & $2.1 \mathrm{a}$ & $0.7 \mathrm{c}$ \\
\hline 1988 & & $223 \mathrm{~b}$ & $2.0 \mathrm{a}$ & $2.0 \mathrm{a}$ & $1.2 \mathrm{~b}$ \\
\hline 1989 & & $266 \mathrm{a}$ & $1.6 \mathrm{c}$ & $2.1 \mathrm{a}$ & $1.4 \mathrm{a}$ \\
\hline
\end{tabular}

${ }^{\mathrm{z}}$ Visual rating of leaf or fruit spray injury, where $1=$ very slight injury; $3=$ borderline acceptability; $5=$ very severe spray injury.

${ }^{\mathrm{y}}$ Rating of fruit for spray injury after washing and rinsing.

${ }^{x}$ Means within columns separated by Duncan's multiple range test, $P \leq 0.05$.

${ }^{\mathrm{w}}$ Average spray temperature for each year $(19.1,19.2,19.5,20.2 \mathrm{C}$, respectively).

Table 3. Effect of year of application on fruit quality of 'Anjou' pears, 1986 to 1989.

\begin{tabular}{lcccc}
\hline \hline & $\begin{array}{c}\text { Fruit } \\
\text { firmness } \\
(\mathrm{N})\end{array}$ & $\begin{array}{c}\text { Soluble } \\
\text { solids } \\
\text { concn } \\
(\%)\end{array}$ & $\begin{array}{c}\text { Titratable } \\
\text { acidity } \\
(\% \text { malic })\end{array}$ & $\begin{array}{c}\text { Fruit } \\
\text { color } \\
(1-5)^{\mathrm{y}}\end{array}$ \\
\hline 1986 & $60.8 \mathrm{a}^{\mathrm{x}}$ & $12.6 \mathrm{c}$ & $0.325 \mathrm{a}$ & $1.5 \mathrm{c}$ \\
1987 & $39.0 \mathrm{~b}$ & $13.0 \mathrm{~b}$ & $0.241 \mathrm{~d}$ & $2.0 \mathrm{~b}$ \\
1988 & $38.6 \mathrm{~b}$ & $13.1 \mathrm{a}$ & $0.294 \mathrm{~b}$ & $2.5 \mathrm{a}$ \\
1989 & $60.3 \mathrm{a}$ & $12.2 \mathrm{~d}$ & $0.278 \mathrm{c}$ & $1.0 \mathrm{~d}$ \\
\hline
\end{tabular}

${ }^{2}$ Fruit quality test: $1986=7$ Jan. 1987; $1987=27$ Dec. 1987; $1988=23$ Dec. 1988; 1989 = 7 Dec. 1989. yVisual rating of fruit, where $1=$ green and $5=$ yellow color.

${ }^{x}$ Means within columns separated by Duncan's multiple range test, $P \leq 0.05$ 
Link Ca sprays, but after washing fruit, we considered the spray markings to be acceptable ( $<3$ rating) for marketing the fruit. Stopit sprays injured leaves and fruit the least, possibly due to a lower Ca content in the spray.

Although fruit firmness, SSC, TA, and external fruit color were not significantly affected by $\mathrm{Ca}$ treatments, differences occurred for fruit quality among years. For example, firm fruit, low SSC, and greener skin of fruit were associated with higher Ca concentrations in fruit peel and cortex. The association of fruit quality with fruit $\mathrm{Ca}$ among years rather than with $\mathrm{Ca}$ treatment may be attributable to the larger differences in $\mathrm{Ca}$ concentrations in the peel between years $\left(450 \mu \mathrm{g} \cdot \mathrm{g}^{-1}\right)$ than between Ca treatments $\left(147 \mu \mathrm{g} \cdot \mathrm{g}^{-1}\right)$.

Because neither early nor late Ca sprays were superior for controlling cork spot, both appear to be important in problem orchards. While early sprays injured leaves and fruit less, late sprays resulted in higher fruit $\mathrm{Ca}$ concentrations than early sprays and also in higher yield and heavier fruit than early + late sprays. We suggest using five $\mathrm{CaCl}_{2}$ sprays at $\approx 3$-week intervals from late May or early June to mid or late August as a viable approach for increasing fruit $\mathrm{Ca}$ and controlling cork spot. In addition, precautions should be taken to avoid unacceptable spray injury to leaves and fruit when spraying with potentially phytotoxic Ca materials by following recommendations in Cooperative Extension Spray Guides.

\section{Literature Cited}

Mason, J.L. and M.F. Welsh. 1970. Cork spot (pit) of 'Anjou' pear related to calcium concentration in fruit. HortScience 5:447.

Michigan State University. 1988. MSTAT. Version 1.0. East Lansing, Mich.

Raese, J.T. 1988. Calcium: Effects on apple and pear disorders and fruit quality. Proc. Wash.
State Hort. Assn. 84:247-257.

Raese, J.T. 1989. Physiological disorders and maladies of pear fruit. Hort. Rev. 11:357-411.

Raese, J.T. and S.R. Drake. 1993. Effects of preharvest calcium sprays on apple and pear quality. J. Plant Nutr. 16:1807-1819.

Raese, J.T. and E.A. Stahly. 1982. Calcium sprays to control physiological disorders of d'Anjou' pears. Acta Hort. 124:119-124.

Raese, J.T. and D.C. Staiff. 1983. Effect of rate and source of nitrogen fertilizers on mineral composition of d'Anjou pears. J. Plant Nutr. 6:769779.

Richardson, D.G. and A.M. Al-Ani. 1982. Cork spot of d'Anjou pear fruit relative to critical calcium concentration and other minerals. Acta Hort. 124:113-118.

Richardson, D.G. and P.B. Lombard. 1979. Cork spot of Anjou pear. Control by calcium sprays. Commun. Soil Sci. Plant Anal. 10:383-389.

Woodbridge, C.G. 1971. Calcium level of pear tissues affected with cork and black end. HortScience 6:451-453. 